FEATURE

Catherine Barham, Annette Walling, Gareth Clancy, Stephen Hicks

and Sarah Conn

\section{Office for National Statistics}

\title{
Young people and the labour market
}

\section{Introduction}

r here has been increasing interest in young people over recent years, for a variety of reasons. Employment rates for people aged 16 and over have been increasing steadily since the mid 1990s, with the exception of those aged under 25 (Figure 1). For those under 25, the decline in employment has been particularly marked among the 16 and 17 year olds. Young people also play an important part in the dynamics of the labour market because they are a source of labour supply. As older people move out of economic activity through retirement, whether voluntary or involuntary, young people are needed to fill the gap. Clearly older people are likely to have acquired a wider range of skills and experience by the time they move out of work and so the process is not simply one of like for like job replacement.. The balances between these changes in supply are important to understand as well as the stages young people go through from education to employment.

The transition between school and work has become longer and more complex in recent years, with the increase in options for further education beyond 16 . Consequently, young people now enter the labour market at a much wider range of ages than previously. In addition, changes in the structure of the labour market over the past two decades have had an impact on the options available to young people. This article investigates these changes and looks at the some of the implications for certain groups of young people.

\section{Population of young people}

One aspect to consider when looking at changing supply over recent years is the change in the structure of population available to work. Although the size of the working age population has increased from just under 35 million in March-May 1992 to just under 38 million in October to December 2008, the proportion of young people aged under 25 has changed relatively little. The proportion of 16 and 17 year olds was the same in March-May 1992 as it was in October to December 2008, making up 4.1 per cent of the working age population. The proportion of young people aged 18-24 dipped to a low of 13.5 per cent in JuneAugust 2000 and has since risen slightly to 15.1 per cent in November to January 2008.

Clearly the composition of the labour force is an important factor when comparing the experiences of groups within the labour market. There have been concerns in the past that the falling birth rate in the 1970s would have a negative impact on the supply of young people into the labour market in the 1990s. This coupled with the increase in the proportions of young people staying on in further education was predicted to result in severe shortages of young people in jobs. This trend does not, however, appear to have materialised, partly due to the increased number of students joining the labour market.

\section{Participation in education}

As mentioned, the increase in the number of students has been one of the major 


\section{Figure 1}

\section{Employment rates by age, March to May 1992 to October to December 2008}

\section{United Kingdom}

Percentages, seasonally adjusted

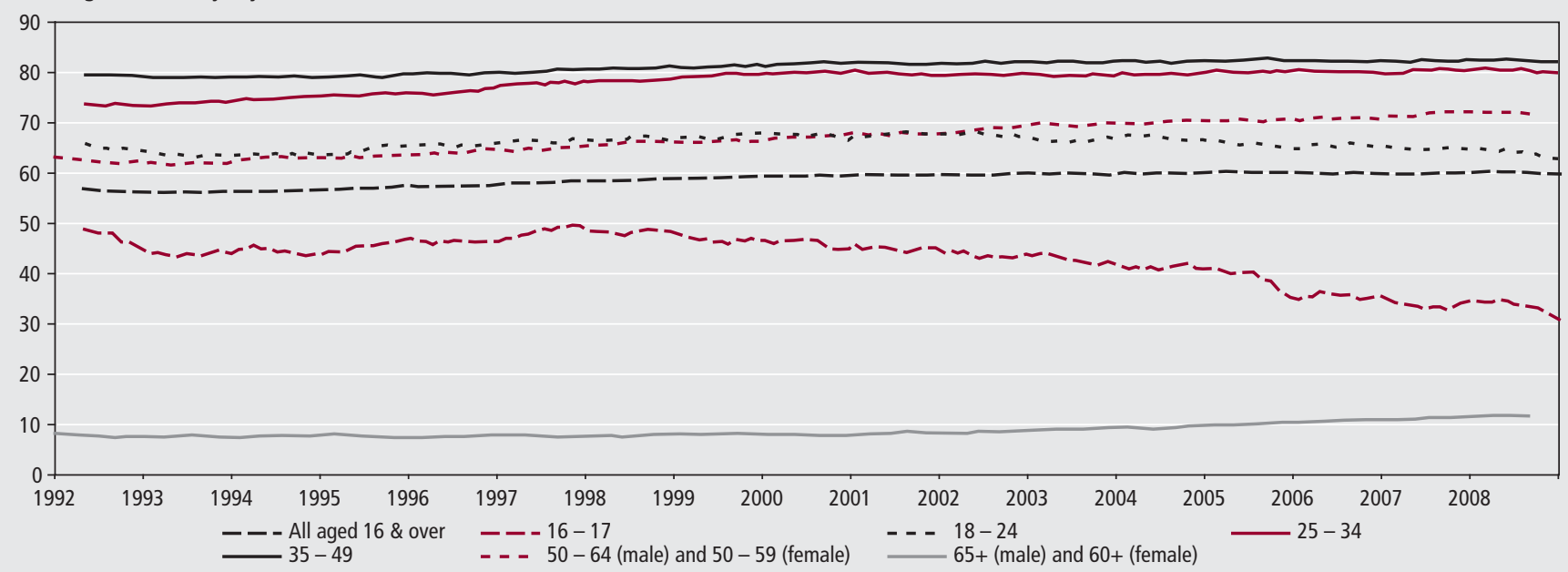

Source: Labour Force Survey

\section{Figure 2}

Percentage of young people in full-time education by age, March to May 1992 to October to December 2008 United Kingdom

Percentages, seasonally adjusted

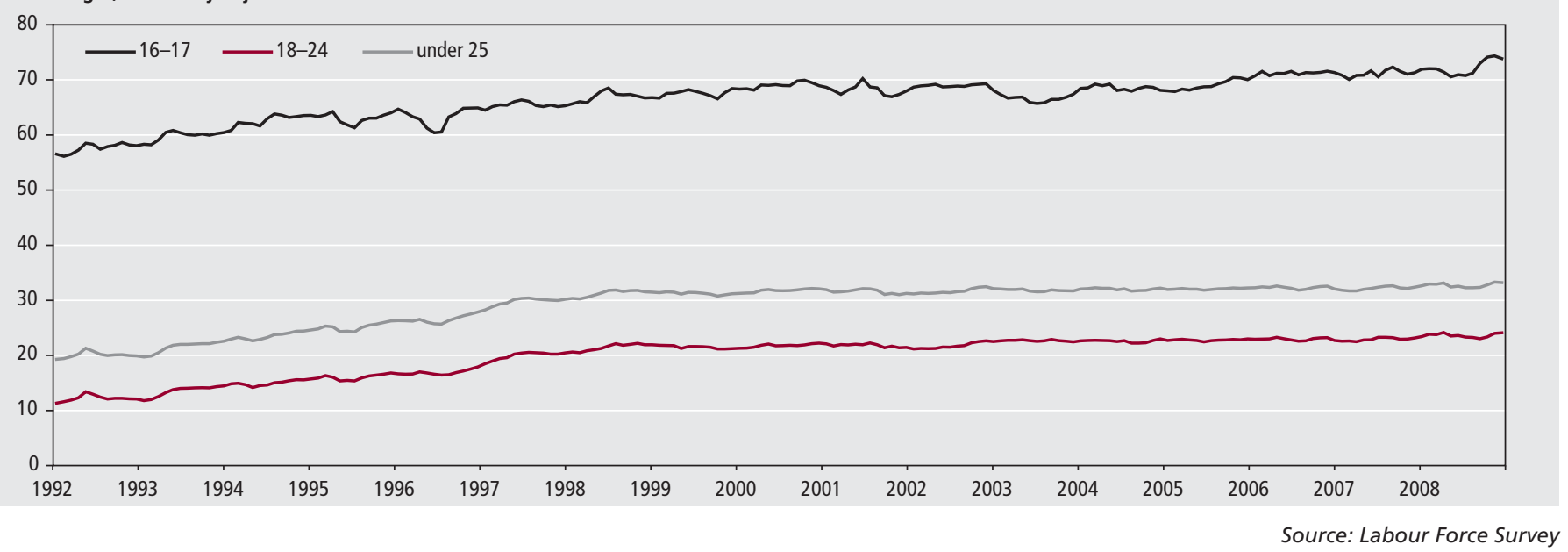

changes impacting on the age and process by which young people enter the labour market. Figure 2 shows these increases in participation in post-compulsory education over the last two decades. Since the first quarter of 1992, the proportion of 16 and 17 year olds in full time education increased from 57 per cent to 74 per cent in the fourth quarter of 2008. A similar increase has been seen among young people aged 18-24. The proportion in full-time education increased from 11 per cent in the same period in 1992 to 24 per cent in quarter four 2008 . Overall, a third of all those aged under 25 were in full-time education at the end of 2008.

These figures are taken from Table 14 of the Labour Market Statistics (LMS) which is published on the National Statistics website on a monthly basis. Analysis carried out for this article identified an improved method of identifying students from the LFS. Further details on the findings of this analysis are given in the technical note but essentially a new method was devised which identified students in any form of education rather than just those on full-time courses. It should be noted that the figures used in the rest of this article are for young people in any education and therefore are not directly comparable with those in the Table 14 of the LMS release.

\section{Sub-groups of young people}

The Labour Force Survey classifies young people in a variety of ways, depending on their economic status. One of the issues with presenting information on young people from the LFS is that it is possible for young people to be in more than one group. For example, students, such as those who are participating in any form of education or training, can also be working for more than one hour in the reference week and will therefore be classified as employed. Most students who are not working will only be classified as economically inactive with the reason for inactivity given as 'student'. Table 1 shows this in more detail.

In 2008,53 per cent of young people aged 16 and 17 were in education and inactive and 28 per cent were in education and also employed. Overall, 89 per cent of this age group were in some form of education. Just over a third of the 16 and 17 year olds were in employment, either in addition to their studies or not, compared with just under two thirds of those aged 18-24. This clearly reflects the completion of studies and movement into employment for some people in this age group. 
Box 1

\section{Technical Note}

Table 14 of the LMS First Release shows estimates of the labour market status of young people by their education status.

Education status is broken down into two groups:

- In full-time education (FTE)

- Not in full-time education

Respondents with unknown education status are put into the 'not in FTE education' category. This has the impact of overestimating the number of young people who are not in FTE and underestimates their economic activity and employment rates, particularly for the 16 and 17 age groups.

The method used in the analysis shown in this article uses an alternative method whereby cases with unknown education status are excluded from the analysis instead of being treated as 'not in FTE'. In addition, the new method also uses responses to additional LFS questions to identify people who are in education. This includes respondents who say they are studying for a qualification, or doing an apprenticeship and those whose reason for inactivity is 'student'.

This article also shows a breakdown of education status using an 'in any education/not in any education' split due to concerns about the assumption that certain types of course are not fulltime, which may not be a valid assumption.

The content of Table 14 is being looked at as a separate strand of work related to this analysis.
Table 1

\section{Education and labour market status of young people by age, average for 2008}

\begin{tabular}{|c|c|c|c|c|c|}
\hline \multirow[t]{2}{*}{ United Kingdom } & \multirow[b]{2}{*}{16} & & \multicolumn{3}{|c|}{ Thousands and percentages } \\
\hline & & 17 & 16-17 & $18-24$ & 16-24 \\
\hline \multicolumn{6}{|l|}{ Per cent } \\
\hline In employment and in education' & 20 & 36 & 28 & 21 & \\
\hline In employment, not in education ${ }^{1}$ & 2 & 8 & 5 & 42 & \\
\hline Total in employment & 22 & 44 & 33 & 64 & \\
\hline Unemployed and in education ${ }^{1}$ & 9 & 7 & 8 & 2 & \\
\hline Unemployed, not in education ${ }^{1}$ & 3 & 5 & 4 & 7 & \\
\hline Total unemployed & 11 & 12 & 12 & 10 & \\
\hline Inactive and in education ${ }^{1}$ & 65 & 42 & 53 & 18 & \\
\hline Inactive, not in education ${ }^{1}$ & 2 & 3 & 2 & 8 & \\
\hline Total inactive & 66 & 45 & 55 & 27 & 3. \\
\hline Total in education ${ }^{1}$ & 94 & 85 & 89 & 42 & 5. \\
\hline Total not in employment, education or training (NEET) ${ }^{1}$ & 4 & 8 & 6 & 15 & \\
\hline Total & 100 & 100 & 100 & 100 & \\
\hline
\end{tabular}

Thousands

\begin{tabular}{lrrrrr} 
In employment and in education & 157 & 284 & 441 & 1,207 & 1,648 \\
In employment, not in education & 15 & 60 & 75 & 2,414 & 2,489 \\
Total in employment $^{2}$ & 175 & 347 & 522 & 3,653 & 4,175 \\
\hline Unemployed and in education & 65 & 55 & 120 & 141 & 261 \\
Unemployed, not in education & 20 & 39 & 59 & 414 & 474 \\
Total unemployed $^{2}$ & 90 & 95 & 184 & 560 & 744 \\
\hline Inactive and in education & 474 & 332 & 805 & 1,043 & 1,848 \\
Inactive, not in education & 11 & 21 & 32 & 469 & 501 \\
Total inactive $^{2}$ & 517 & 354 & 872 & 1,520 & 2,392 \\
\hline Total in education $^{2}$ & 696 & 670 & 1,366 & 2,391 & 3,757 \\
\hline Total not in employment, education or training (NEET) & 31 & 61 & 92 & 883 & 974 \\
\hline Total $^{2}$ & 782 & 796 & 1,578 & 5,733 & 7,311 \\
\hline
\end{tabular}

Notes:

Source: Labour Force Survey

1 Base for percentages excludes people with unknown education status.

2 Totals include people with unknown education status.
It is worth mentioning at this stage that 13 per cent of the 16-24 age group were not in employment, education or training (NEET) in 2008. This sub-group is of interest to policy makers and labour market commentators due to the implications this may have for the future labour market experiences of these people and is covered in more detail in a later section.

\section{Young people in employment}

Young people, particularly those aged 16 and 17 who are not in any form of education, appear to have been experiencing decreases in employment rates and increases in unemployment since around the late 1990s. The increases in participation in education post 16 are one factor in explaining this trend. An additional issue to consider is the wider change to the structure of the labour market in terms of industrial sectors which may have had a fundamental impact on the demand for young people's labour. In general terms, there has been a decline in industrial and agricultural employment and a growth in the size of the service sector since the late 1970s. The manufacturing industry was the largest industry in September 1978, comprising 26 per cent of all employee jobs. It has fallen to being the fourth largest industry in September 2008 , with only 10 per cent of employee jobs, behind public administration, distribution, hotels and restaurants and the banking sectors. The decline in the manufacturing sector is likely to have had a particular impact on young people as craft apprenticeships were an important route into the labour market particularly for males (Felstead et al 1999).

Table 2 shows the industries in which young people were working in 1995 and 
Table 2

Percentage breakdown of young people in employment by industry, averages for 1995 to 2008

United Kingdom

Percentages

\begin{tabular}{|c|c|c|c|c|c|c|c|c|c|c|c|}
\hline & \multicolumn{11}{|c|}{$16-17$} \\
\hline & $\begin{array}{r}\text { Agriculture \& } \\
\text { fishing } \\
(A, B)\end{array}$ & $\begin{array}{r}\text { Mining, } \\
\text { energy \& water } \\
(\mathrm{C}, \mathrm{E})\end{array}$ & $\begin{array}{r}\text { Manufacturing } \\
\text { (D) }\end{array}$ & $\begin{array}{r}\text { Construction } \\
\text { (F) } \\
\end{array}$ & $\begin{array}{r}\text { Distribution, } \\
\text { hotels and } \\
\text { restaurants } \\
(\mathrm{G}, \mathrm{H})\end{array}$ & $\begin{array}{r}\text { Transport, } \\
\text { storage and } \\
\text { communications } \\
\text { (I) }\end{array}$ & $\begin{array}{r}\text { Finance \& } \\
\text { business } \\
\text { services }(\mathrm{J}, \mathrm{K}) \\
\end{array}$ & $\begin{array}{r}\text { Public } \\
\text { administration, } \\
\text { education and } \\
\text { health }(\mathrm{L}, \mathrm{M}, \mathrm{N})\end{array}$ & $\begin{array}{r}\text { Other services } \\
(0-Q) \\
\end{array}$ & $\begin{array}{r}\text { Total Services } \\
(\mathrm{G}-\mathrm{Q}) \\
\end{array}$ & Total \\
\hline 1995 & * & * & 12 & 5 & 58 & 2 & 5 & 6 & 9 & 81 & 100 \\
\hline 1996 & * & * & 12 & 4 & 59 & 2 & 5 & 6 & 9 & 81 & 100 \\
\hline 1997 & 2 & 0 & 12 & 4 & 58 & 2 & 5 & 6 & 10 & 82 & 100 \\
\hline 1998 & 2 & 0 & 11 & 5 & 60 & 2 & 5 & 6 & 9 & 82 & 100 \\
\hline 1999 & 1 & 0 & 10 & 5 & 61 & 2 & 5 & 5 & 10 & 83 & 100 \\
\hline 2000 & 1 & 0 & 8 & 5 & 61 & 2 & 5 & 6 & 10 & 86 & 100 \\
\hline 2001 & * & * & 9 & 5 & 62 & 2 & 5 & 6 & 9 & 85 & 100 \\
\hline 2002 & * & * & 8 & 6 & 64 & 2 & 5 & 6 & 9 & 85 & 100 \\
\hline 2003 & * & * & 6 & 6 & 64 & 2 & 4 & 6 & 10 & 86 & 100 \\
\hline 2004 & 1 & 0 & 6 & 6 & 63 & 2 & 4 & 7 & 11 & 87 & 100 \\
\hline 2005 & * & * & 6 & 6 & 65 & 2 & 4 & 6 & 10 & 87 & 100 \\
\hline 2006 & * & * & 4 & 7 & 64 & 2 & 4 & 6 & 12 & 87 & 100 \\
\hline 2007 & 1 & 0 & 4 & 7 & 66 & 1 & 4 & 5 & 11 & 87 & 100 \\
\hline 2008 & 1 & 0 & 5 & 7 & 62 & 2 & 3 & 8 & 12 & 87 & 100 \\
\hline
\end{tabular}

\begin{tabular}{|c|c|c|c|c|c|c|c|c|c|c|c|}
\hline & \multicolumn{11}{|c|}{$18-24$} \\
\hline & $\begin{array}{r}\text { Agriculture \& } \\
\text { fishing } \\
(\mathrm{A}, \mathrm{B}) \\
\end{array}$ & $\begin{array}{r}\text { Mining, } \\
\text { energy \& water } \\
(C, E) \\
\end{array}$ & $\begin{array}{r}\text { Manufacturing } \\
\text { (D) }\end{array}$ & $\begin{array}{r}\text { Construction } \\
\text { (F) } \\
\end{array}$ & $\begin{array}{r}\text { Distribution, } \\
\text { hotels and } \\
\text { restaurants } \\
(\mathrm{G}, \mathrm{H})\end{array}$ & $\begin{array}{r}\text { Transport, } \\
\text { storage and } \\
\text { communications } \\
(\mathrm{I}) \\
\end{array}$ & $\begin{array}{r}\text { Finance \& } \\
\text { business } \\
\text { services }(\mathrm{J}, \mathrm{K}) \\
\end{array}$ & $\begin{array}{r}\text { Public } \\
\text { administration, } \\
\text { education and } \\
\text { health }(\mathrm{L}, \mathrm{M}, \mathrm{N}) \\
\end{array}$ & $\begin{array}{r}\text { Other services } \\
(0-Q)\end{array}$ & $\begin{array}{r}\text { Total Services } \\
(\mathrm{G}-\mathrm{Q}) \\
\end{array}$ & Total \\
\hline 1995 & 2 & 1 & 19 & 7 & 30 & 5 & 15 & 15 & 7 & 72 & 100 \\
\hline 1996 & 2 & 1 & 19 & 6 & 31 & 5 & 14 & 15 & 7 & 73 & 100 \\
\hline 1997 & 1 & 1 & 18 & 6 & 33 & 5 & 14 & 14 & 7 & 74 & 100 \\
\hline 1998 & 1 & 1 & 18 & 6 & 33 & 5 & 15 & 13 & 8 & 74 & 100 \\
\hline 1999 & 1 & 1 & 16 & 6 & 33 & 6 & 16 & 14 & 8 & 76 & 100 \\
\hline 2000 & 1 & 1 & 15 & 6 & 33 & 6 & 16 & 14 & 7 & 77 & 100 \\
\hline 2001 & 1 & 1 & 14 & 7 & 33 & 6 & 17 & 15 & 7 & 77 & 100 \\
\hline 2002 & 1 & 1 & 13 & 7 & 33 & 6 & 16 & 16 & 7 & 78 & 100 \\
\hline 2003 & 1 & 1 & 12 & 8 & 35 & 5 & 15 & 16 & 8 & 79 & 100 \\
\hline 2004 & 1 & 1 & 10 & 8 & 36 & 5 & 14 & 17 & 8 & 80 & 100 \\
\hline 2005 & 1 & 1 & 10 & 9 & 35 & 5 & 14 & 16 & 8 & 79 & 100 \\
\hline 2006 & 1 & 1 & 9 & 9 & 35 & 5 & 15 & 16 & 8 & 79 & 100 \\
\hline 2007 & 1 & 1 & 10 & 9 & 34 & 5 & 15 & 16 & 8 & 78 & 100 \\
\hline 2008 & 1 & 1 & 9 & 9 & 36 & 4 & 14 & 16 & 9 & 80 & 100 \\
\hline
\end{tabular}

Note:

Source: Labour Force Survey

* Sample too small to provide an estimate.

0 cells indicate percentage is less than 1 .

2008. What is immediately apparent is that there is a distinct concentration of young people in a few industry groups, particularly among those who are in some form of education. Among 16-24 year olds, the proportion of all employed young people of this age in the service sector has increased over the last decade from 73 per cent in 1995 to 81 per cent in 2008. Young people aged 16, 17 were most commonly working in distribution, hotels and restaurant sectors and this proportion has changed relatively little over the period. What is also interesting is that the proportions of both the 16, 17 and 18-24 age groups working in manufacturing has more than halved over the period.

This shift away from manufacturing and towards the service sector has changed not only the number of jobs in different industry groups, but also the types of jobs available in these sectors. Jobs in the manufacturing industry were primarily full-time whereas the expansion of the service sector has seen an increase in parttime work and other non-standard forms of employment (Felstead 1999). These structural shifts have also meant changes to the distribution of occupations. Although there has been an expansion in the lower level personal service and sales occupations, the general trend has been a growth in the higher level 'white collar' occupations. The shift away from manufacturing has also meant there has been a decline in most manual occupations. These factors have all contributed to make the labour market harder for those with low skill and qualification levels, including young people. Alongside these changes, it should also be noted that young people are increasingly less likely to have low skills and/or no qualifications.

As young people make the transition from education into employment, they come into direct competition with adult workers. Young people are, by definition, less experienced, probably less skilled in work terms, require more training and may, as a result of their lower cost, be a more flexible workforce. In some industries, these factors will mean that young people are in competition with unskilled and adult workers with lower education levels and therefore tend to be more concentrated in occupations where the demand for these types of jobs is higher.

Table 3 indicates that in 2008, young people aged 16-24 were more likely to be in elementary and sales and customer service occupations than any of the higher managerial groups. The pattern by age shows that among the 18-24 year olds, there is a movement into the higher groups with just under 10 per cent being employed as managers and senior officials and 
Table 3

Young people in employment by occupation and age, average for 2008

United Kingdom

\begin{tabular}{lrrr}
\hline Standard Occupation Classification (SOC) 2000 & 16-17 & 18-24 & All aged 16-24 \\
\hline 1 Managers and Senior Officials & $*$ & 4 & 4 \\
2 Professional occupations & $*$ & 5 & 5 \\
3 Associate Professional and Technical & 3 & 12 & 11 \\
4 Administrative and Secretarial & 4 & 12 & 11 \\
5 Skilled Trades Occupations & 9 & 12 & 11 \\
6 Personal Service Occupations & 9 & 10 & 10 \\
7 Sales and Customer Service Occupations & 35 & 19 & 21 \\
8 Process Plant and Machine Operatives & 1 & 5 & 5 \\
9 Elementary Occupations & 37 & 20 & 22 \\
& & & 100 \\
Total & 100 & 100 & \\
\hline
\end{tabular}

Note:

* Sample too small to provide an estimate.

Source: Labour Force Survey

professional occupations. This is still a much lower proportion compared with all people aged 16 and over, 28 per cent of whom were in the managerial and profession groups in 2008. This is perhaps to be expected given the link with experience for some of the jobs within this category.

The LFS can also be used to look at the proportion of temporary jobs among young people in work by their education status. While it is clear that a relatively small proportion of young people are in this type of employment (17 per cent of 16-17 year olds and 12 per cent of 18-24 year olds in 2008), there appears to be a distinction between the type of jobs taken by young people in education compared to those who are not. Around 17 per cent of all young employees aged 16 and 17 were in temporary jobs in 2008 whereas for those aged 18 to 24,17 per cent of those in education were in temporary jobs compared with only 9 per cent of those not in education.

Table 4 shows the responses given when respondents were asked for the reason why they were in a temporary job. Over a half of young people aged 16-24 in education gave their reasons as being 'did not want a permanent job'. The pattern changes significantly for those young people who were not in education as 48 per cent of those aged 16 and 17 gave their reason as 'could not find a permanent job'.

\section{Education and Skills of Young People}

People often forego earnings early on in their career to develop additional skills from education and training. While young people consider the amount they wish to invest in themselves, firms must consider both the cost of a workers salary and the training when deciding who and how

\section{Figure 3}

many people to recruit. For each individual employee these employee costs are known as the marginal cost of an employee, and in the short term firms will hire until the marginal cost of the additional worker is equal to the monetary value of the output that worker produces (the marginal product).

Figure 3 shows that the recruitment of young people increases as the size of the firm increases. This information comes from the National Employer Skills Survey rather than the Labour Force Survey. Only 34 per cent of firms with five to 24 employees in 2007 have recruited young workers, whereas 73 per cent of firms of 500 employees or more have recruited young workers. This fits with the theory that larger firms are able to take more risks, for example employing younger or inexperienced workers, because by recruiting higher numbers of people the average cost of recruiting falls. The training opportunities may also be greater in larger firms, which attracts younger workers or people with lower than average experience.

One way young people can enter the workforce and build up new skills is through an apprenticeship. People working in the manufacturing and construction industries account for almost half of the

\section{Recruitment of young people by size of firm, 2008}

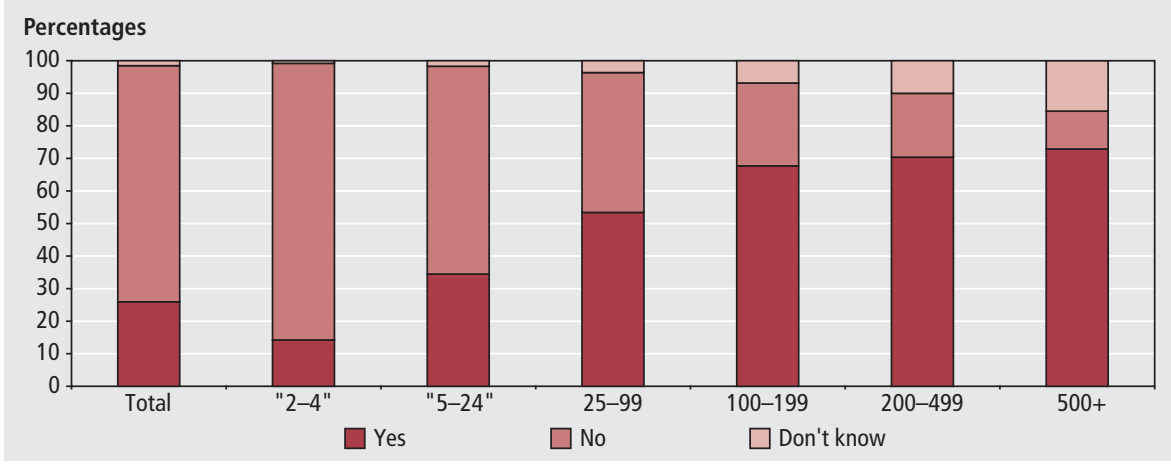

Source: National Employers Skills Survey

Table 4

Temporary workers by reasons for taking a temporary job, by education status and age, average for 2008 United Kingdom

\begin{tabular}{|c|c|c|c|c|c|c|c|c|c|}
\hline & \multicolumn{3}{|c|}{ In education } & \multicolumn{3}{|c|}{ Not in education } & \multicolumn{3}{|c|}{ Total $^{1}$} \\
\hline & $16-17$ & $18-24$ & $16-24$ & $16-17$ & $18-24$ & $16-24$ & $16-17$ & $18-24$ & $16-24$ \\
\hline Contract includes a period of training & 6 & 9 & 8 & * & 6 & 6 & 6 & 7 & 7 \\
\hline Contract for probationary period & 3 & 2 & 2 & * & 7 & 8 & 4 & 5 & 5 \\
\hline Could not find permanent job & 8 & 7 & 7 & 48 & 40 & 40 & 13 & 24 & 22 \\
\hline Did not want permanent job & 53 & 50 & 51 & 14 & 17 & 17 & 48 & 34 & 36 \\
\hline Some other reason & 30 & 32 & 32 & 20 & 30 & 29 & 28 & 31 & 30 \\
\hline Total & 100 & 100 & 100 & 100 & 100 & 100 & 100 & 100 & 100 \\
\hline
\end{tabular}

\section{Notes:}

1 Total includes employees with unknown education status.

* Sample too small to provide an estimate. 
apprenticeships in the UK economy. As mentioned earlier, given that the manufacturing sector has declined in importance in the UK economy, the means of entry into the workforce has changed for young people.

Table 5 shows the percentage of young people who have done, or are doing, an apprenticeship in each industry in 2008. The construction industry had the largest percentage of young people with an apprenticeship, at 41 per cent. This was then followed by the energy and water and manufacturing industries at 23 per cent and 20 per cent respectively. The industries with the lowest percentage of young people with apprenticeships were the distribution hotels \& restaurants and banking, finance \& insurance industries, both with 4 per cent.

This distribution of apprenticeships across industries has remained consistent over time, with the construction industry having the highest proportion of young people with apprenticeships for the last ten years. The energy \& water and manufacturing industries have also been in the top four industries, along with other services. The distribution hotels and restaurants industry has fallen slightly over the last ten years, but it was always part of the lowest three industries for young people with apprenticeships, along with the banking, finance \& insurance and public admin, education \& health industries.

The majority of work based learning takes place as on the job training. As one would expect, job-related training is more concentrated among young people as they are able to use training as a trade off for experience. Figures from the LFS for 2008 indicate that for those young people in employment, around 40 per cent had received some form of on-the job training in the previous three months compared to 27 per cent for those of working age as a whole. This proportion drops off to around a third of those in the 18-24 age group receiving training and to just over a fifth of those in the 50 to retirement age group.

The age profile for on-the job training fits well with economic theory on human capital investment and age earning profiles.

Table 5

\section{Percentage ${ }^{1}$ of young people in employment who have completed or are currently doing an apprenticeship by industry sector of main job, 16-24 year-olds, average for 2008}

United Kingdom

Percentages

\section{Industry}

A-B: Agriculture \& fishing

(1)

C E: Energy \& water

D: Manufacturing

F: Construction

G-H: Distribution hotels \& restaurants

I: Transport \& communication

J-K: Banking finance \& insurance etc

L-N: Public admin education \& health

O-Q: Other services

Figure 4
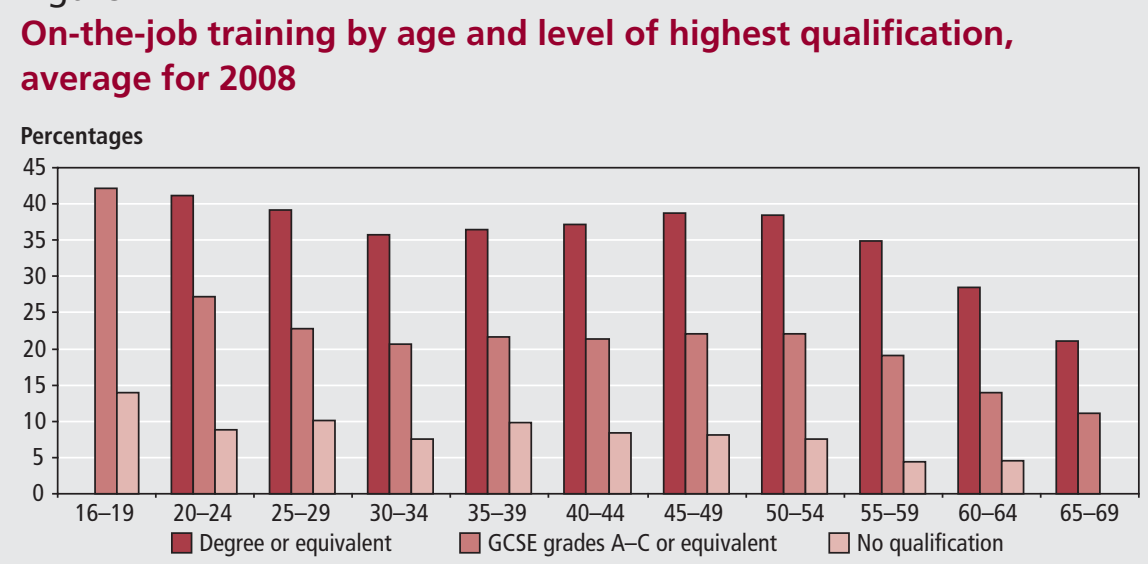

Source: Labour Force Survey

Younger workers earn less because they are investing in human capital, which means that they are paid less as this 'investment' or training takes place on-the-job. As a worker ages, their earnings profile is upward sloping because of they begin to receive the reward from this earlier investment in training.

Figure 4 illustrates that a large percentage of people undertook on the job training in 2008, but there are differences by level of educational attainment. For those with their highest qualification as 'degree or equivalent', each age category up to and including the 55-59 group had more than 30 per cent of those employed receiving on the job training in the last three months. The initial training for entrants to the labour market from the GCSE educated group was comparable to that of the 'degree or equivalent' group (comparing those aged 16-19 with GCSE qualifications to those people aged 20-24 with degree or equivalent). However, there was an immediate reduction in on the job training from 42 per cent for the 16-19 year olds to 27 per cent for the 20-24 year age group for GCSE educated people, after which it levels off.

People with 'no qualifications' received the lowest amount of on the job training across all age groups. This chart also shows that overall, regardless of people's highest qualification, on the job training reduces noticeably from the age of 60 years.

As Hasluck (1998) states in his review of research on young people, employers are increasingly looking for more skilled workers and frequently use qualifications as an indicator of technical capabilities. For those people who do not make the transition from school to work, joining a government scheme is another option. Since the 1970s and early 1980s different approaches have been taken by governments to help young and unemployed people into work. Although the details vary from programme to programme, the general concept is the same, that employers provide a training place while the young person either continues to receive benefits or is paid a training allowance (either by the government or the employer).

There has been a dramatic reduction in the numbers on government training schemes since the early 1990s: the numbers of 16 and 17 year olds have reduced from a peak of 70,000 in 1997 to 31,000 in 2005. Young people aged 18-24 are now more likely to be on a scheme than those aged 16 and 17: almost 50,000 were in 2005, a 
reduction from 77,000 in 1997 . Some of this decline can be explained by the changes in the policical and economic context over this period. For example, the gradual removal of youth training scheme guarantee and the introduction of the New Deal for Young People have meant fewer people are likely to be on these schemes.

\section{Earnings of young people}

This section of the article brings together data from the Annual Survey of Hours and Earnings (ASHE) and the Labour Force Survey (LFS) to analyse the earnings of young people. The ASHE is the ONS's preferred source for earnings analysis and has been used wherever possible. However, the LFS is used when looking at characteristics which are not available from the ASHE.

Figure 5 shows that the median hourly earnings excluding overtime of full-time employees aged 16 to 24 was $£ 7.39$ per hour in April 2008 (includes those on junior rates of pay). As expected, this is lower than older age groups where full-time employees aged 25 to 34 years earned $£ 11.92$ per hour, 35 to 49 year olds $£ 13.37$ and those aged 50 and over $£ 12.04$. In percentage terms, 25 to 34 year olds earned 38 per cent more on average than 16 to 24 year olds, 35 to 41 year olds 45 per cent more and employees aged 50 and over 39 per cent more.

Since 1997, median earnings of young employees has grown at a very similar rate to the earnings of older employees. This has resulted in the pay gap between older and younger employees remaining fairly constant over the period. Since 2003, there has, however, been a slight increase in the pay gap between full-time employees aged 50 and over and those aged 16 to 24 .

As well as looking at the differences between average earnings of younger and older age groups it is also possible to look at the differences in pay within the different age groups. By looking at the distribution of earnings, it is possible to look at how large the gap is between low paid and high paid workers within each age group. The distribution of pay, and the change over time, for younger employees can then be compared with that of older employees.

Figure 6 shows the ratio of the amount that the top 10 per cent of full-time employees earned per hour compared with the amount the bottom 10 per cent earned (the 90/10 ratio), by age group, since 1997. It firstly shows, as expected, there is a much smaller difference in young people's pay than older workers pay, in that the distribution of pay for young people is narrower than it is for older groups of employees. In April 2008, the 90th percentile of hourly earnings was 2.25 times higher than the 10th percentile for full-time employees aged 16 to 24 . This compares with a difference of almost four times for full-time employees aged 35 to 49 and 50 years and over, and more than three times for full-time employees aged 25 to 34 . The 90/10 ratio for older groups of employees has remained fairly stable between 1997 and 2008. However (as Figure 6 also illustrates), the distribution of pay for young people (aged 16 to 24 years) has narrowed since 1997 with the $90 / 10$ ratio closing by 19 per cent over this period from 2.78 in 1997 to 2.25 in 2008 .

Figure 7 suggests that this narrowing of the earnings distribution for young people over the period 1997 to 2008 has mainly occurred because of compression in the lower end of the earnings distribution. This is seen by comparing the median pay with the amount that the bottom 10 per cent of the earnings distribution earned beneath (the $50 / 10$ ratio). In 2008 , the $50 / 10$ ratio for 16 to 24 year old full-time employees was 1.36 compared with 1.60 in 1997 representing a 15 per cent reduction over the period. Comparing this with the change in the 90/10 ratio (19 per cent) illustrates that the majority of the narrowing in earnings for young people has been from the lower half of the earnings distribution.

One possible reason for this narrowing could be the introduction of the National Minimum Wage (NMW). The adult rate (for workers 22 and over) and the youth development rate (for 18 to 21 year olds) were introduced in 1999 and a further rate for 16 to 17 year olds was introduced in 2004. Young people are more likely to be earning below the NMW rates and therefore more likely to have benefited from this legislation since its introduction. For example, in April 2008, 3.9 per cent of 16 and 17 year old employees were in jobs paid below the NMW compared with 2.6

\section{Figure 5}

\section{Median hourly earnings ${ }^{1}$ of full-time employees, ${ }^{2}$ April 2008}

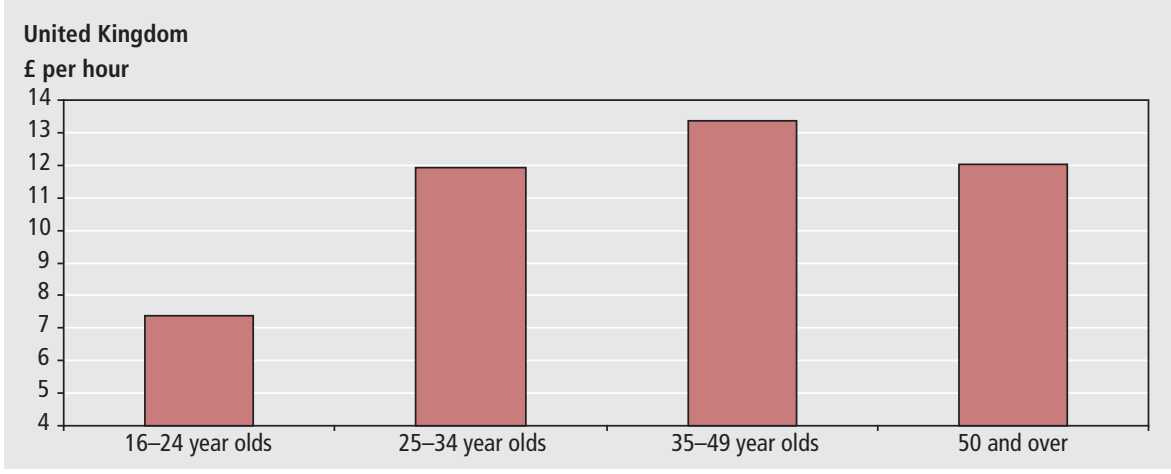

Notes:

Source: Annual Survey of Hours and Earnings

1 Hourly earnings excluding overtime for full-time employees, whose pay for the survey period was not affected by absence.

2 Includes employees not on adult rates of pay.

\section{Figure 6}

\section{$90 / 10$ ratio of hourly earnings ${ }^{1}$ of full-time employees ${ }^{2}$}

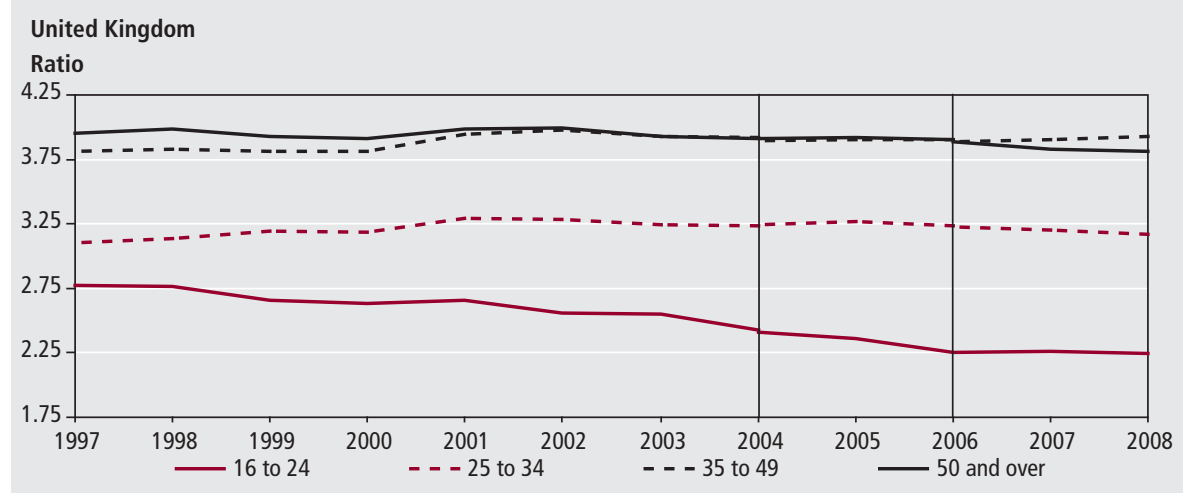

\section{Notes:}

Source: Annual Survey of Hours and Earnings

1 Hourly earnings excluding overtime for full-time employees, whose pay for the survey period was not affected by absence.

2 Includes employees not on adult rates of pay.

3 Vertical lines represent discontinuities in 2004 and 2006 ASHE results. 


\section{Figure 7}

\section{$50 / 10$ ratio of hourly earnings ${ }^{1}$ of full-time employees ${ }^{2}$}

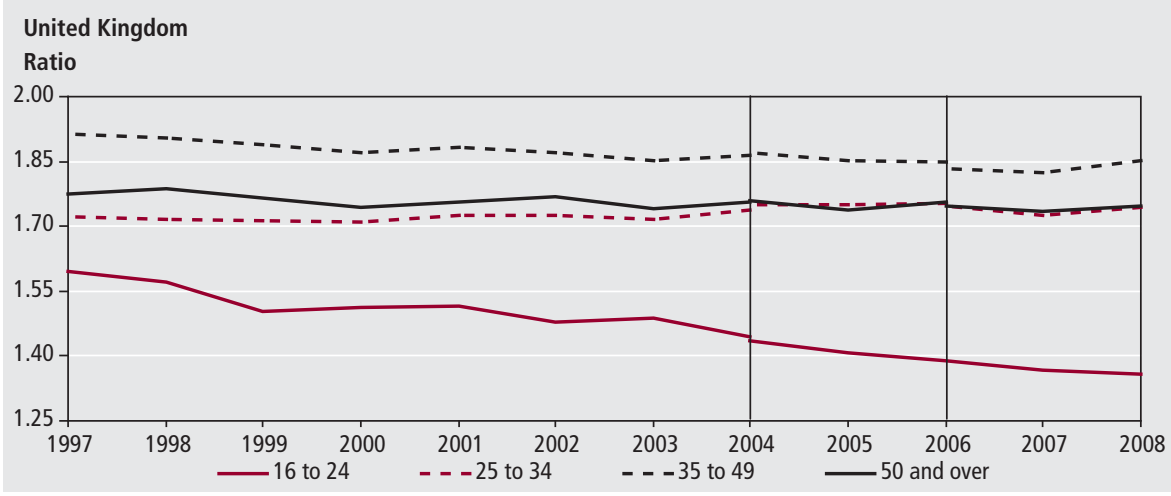

Notes:

Source: Annual Survey of Hours and Earnings

1 Hourly earnings excluding overtime for full-time employees, whose pay for the survey period was not affected by absence.

2 Includes employees not on adult rates of pay.

3 Vertical lines represent discontinuities in 2004 and 2006 ASHE results.

\section{Figure 8}

\section{Median gross hourly pay ${ }^{1}$ for full-time employees by highest qualification and age group, April to June 2008}

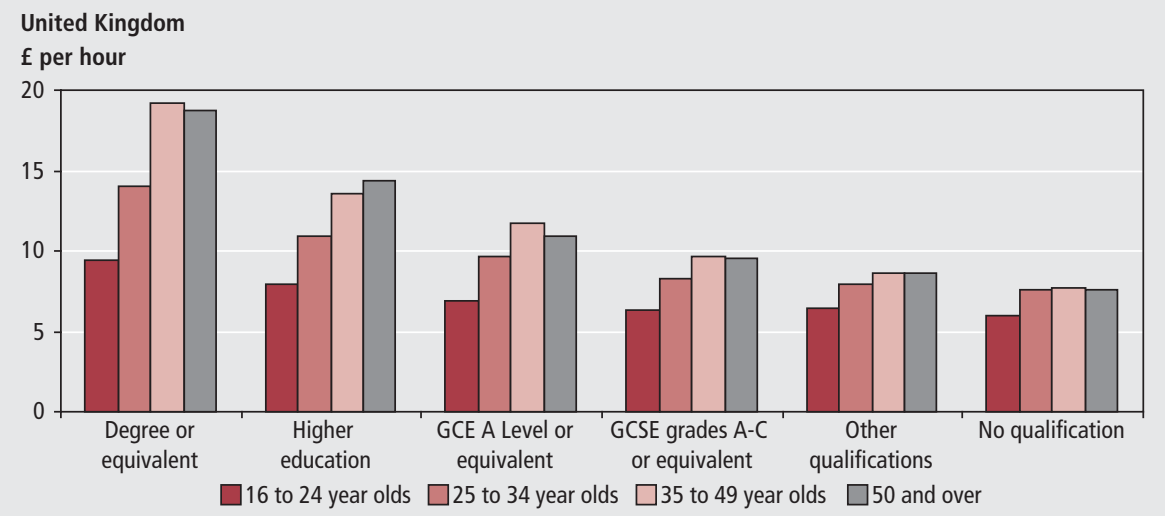

Note:

Source: Labour Force Survey

1 Gross hourly earnings including overtime for full-time employees

per cent of 18 to 21 year olds and 0.9 per cent of employees aged 22 and over. For further information on the characteristics of those paid below the NMW see Hicks S, et al 2009.

Estimates from the Labour Force Survey show that there are large differences in earnings by the level of highest qualification for employees. In April to June 2008, 16 to 24 year old full-time employees with a degree or equivalent as their highest qualification earned on average 58 per cent more than full-time employees with no qualifications ( $£ 9.47$ compared with $£ 6.00$ per hour) (see Figure 8). It should be noted that this difference can partly be explained by the age and experience of young people as well as their qualification level. This is because young people with degrees will be aged 21 and over, whereas those with no qualification could be any age between 16 and 24. Young people aged 16 to 24 who were full-time employees with
GCSE grades A-C or equivalent earned on average $£ 6.35$ per hour, those with GCE A level or equivalent qualifications earned on average $£ 6.90$ per hour and those with higher education level qualifications earned on average $£ 7.89$ per hour. Figure 8 also shows that the difference in median earnings between employees with higher qualifications and those with none is larger for older employees. For example, the median earnings of workers aged 50 and over with degrees and equivalent as their highest qualification were 147 per cent higher than those with no qualifications

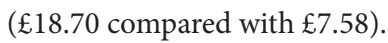

The average earnings of young people also differ by occupation. In April 2008, the ASHE estimates that the median hourly earnings of young full-time employees (aged 16 to 24) in elementary occupations (£6.24 per hour), process plant machine operatives (£6.91), sales and customer sales occupations (£6.61) and personal services occupations (£6.50) were similar. Young people in skilled trade occupations and administrative and secretarial occupations earned $£ 7.15$ and $£ 7.89$ respectively, and the top three occupational groups in terms of levels of earnings were the associate professional and technical occupations (£9.70), professional occupations ( $£ 11.88)$ and managers and senior officials (£9.13). The difference in median earnings between higher and lower occupational groups increases with age. For example, the median earnings of 35 to 49 year old full-time employees in professional occupations is 150 per cent higher than those in elementary occupations compared with only 90 per cent for full-time employees aged 16 to 24 .

\section{Young people who are unemployed}

Headline figures show that unemployment rates for young people have been increasing in recent years, particularly among those aged 16 and 17 , since around the middle of 2000. This is in contrast to other rates for the older age group which have stayed relatively constant since 2000 , until the most recent upturn. The unemployment rate for 16 and 17 year olds peaked in the period July-September 2007 at 28.8 per cent, whereas for those young people age 18-24, the peak was back in February-April 1993 at 17.8 per cent.

It appears from this that it is those aged 16 and 17 who have experienced the more substantial rises in unemployment and falls in employment over this period despite the general improvement in the economy up until the third quarter of 2008. Unemployment rates by education status show an interesting pattern: although unemployment rates for 16,17 year olds not in education are around double those for young people of the same age who are in education, the rates of increase since 2000 have in most cases been larger for the in education group.

Falls in unemployment since 2000 are likely to be related to the New Deal for Young People (NDYP) which has helped to reduce unemployment and particularly long-term unemployment among this age group. This scheme was introduced in April 1998 as one of the key parts of the government's welfare to work strategy and is aimed at young people aged 18 to 24 who have been claiming Jobseekers Allowance for at least six months. The scheme is intended to help them find sustainable employment jobs and increase their long-term employability. Participation 
in the scheme is mandatory and there are a number of options open to those who do not find a job. These include a period of full-time education or training and work experience through job placements and subsidised employment. The numbers of young people participating on the scheme peaked in July 1999 at just under 146,000 participants and have subsequently fallen to just under 78,000 in August 2008. Analysis of the long-term impact of the NDYP has, however, indicated that by the first half of 2000 NDYP had generated about 25,000 jobs (including those in subsidised employment) of which 10,000 went to people outside the NDYP age group. This indicates that the impact of the NDYP is wider than just direct participants.

Information on duration of unemployment is available from the LFS broken down by age. This indicates that for the 16,17 age group, just over three quarters were unemployed for under six months in October to December 2008 and only 8 per cent were unemployed for over 12 months. These proportions change for the 18-24 age group as 16 per cent were unemployed for between 6 and 12 months and 18 per cent were unemployed for over 12 months.

In terms of labour supply, the unemployed group is considered to be relatively close to the labour market and indeed transition rates back into employment are much higher than for the group of people classified as inactive. This is why the focus of interest in recent year has widened from solely looking at unemployed young people to the group who, following the end of compulsory education, are not in employment, education or training. These people are often referred to using the abbreviated term 'NEET' (Not in Education, Employment or Training).

\section{Young people not in education, employment or training (NEETs)}

Since 2001, the proportion of young people aged 16-24 who are NEET has remained fairly stable at around 13 per cent (Figure 9). There are some slight differences by age as there has been a decline in the proportion of 16 year olds who are NEET (from 7 per cent in 2001 to 4 per cent in 2008) and a slight increase in the proportion of 18-24 year old men who are NEET (from 11 per cent in 2001 to 13 per cent in 2008). Young women are more likely to be NEET than young men: 15 per cent of those aged 16-24 were NEET compared with 11 per cent of men of the same age although the opposite is true in the 16,17 age group where men are more likely to be NEET than women of the same age.

Clearly it is possible to be NEET at any age but the interest is particularly on young people due to the possible implications that being NEET may have on future labour market experiences. Overall, young people aged 16-24 account for 14 per cent of all people who are NEET and of working age.

The proportions of young people who are NEET varies only slightly by government office region across the UK. Figures from the Annual Population Survey (APS) for 2007 show that for the 16,17 age group, the

\section{Figure 9
Percentage of young people not in employment, education or training (NEET) by age, average for each year 2001 to 2008

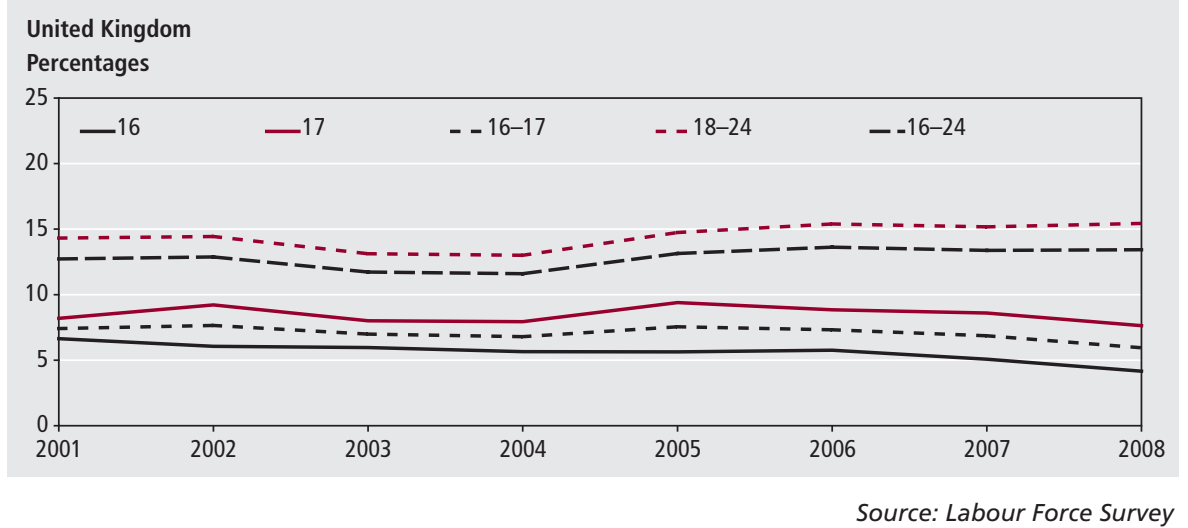

\section{Box 2}

\section{Technical Note}

The Labour Market section of ONS has been working on a method for measuring NEETs for the UK as a whole from the Labour Force Survey. The Department for Children Schools and Families (DCSF) and the Welsh Assembly publish figures on NEETs, based mainly on administrative data, and these are the principal source of figures on NEETs for England and Wales. These figures will not be comparable to the ones shown here as the figures in this article are for the UK as a whole and use only the LFS.

DCSF also publish information on NEETs from the LFS on a quarterly basis and these figures are also not directly comparable with the figures shown here, mainly due to the fact that they are based on academic age rather than actual age as shown here.

\section{Table - LFS Variables used in the new definition of NEETs}

\begin{tabular}{lll}
\hline Variable name & Categories & Who captured \\
\hline $\begin{array}{l}\text { Basic economic activity } \\
\text { INECACR }\end{array}$ & $5,7-12,14-23,24-33$ & Not in employment and reason for inactivity not student \\
$\begin{array}{l}\text { Current education } \\
\text { CURED }\end{array}$ & 11,13 & Enrolled but not attending and not enrolled on course \\
$\begin{array}{l}\text { CURED8 (from JM08) } \\
\text { Recognised trade apprenticeship }\end{array}$ & 1,4 & $\begin{array}{l}\text { Not recognised as doing an apprenticeship or completed } \\
\text { apprenticeship }\end{array}$ \\
$\begin{array}{l}\text { APPREN (spring 92 to Winter 03) } \\
\begin{array}{l}\text { APPR4 (spring 04 to OD07) } \\
\text { APPR8 (from JM08) }\end{array}\end{array}$ & Not working or studying for qualification \\
$\begin{array}{l}\text { Whether working or studying towards a } \\
\text { qualification } \\
\text { QULNOW }\end{array}$ & 2 & \\
\hline
\end{tabular}


Table 6

\section{Young people by whether they are NEET by highest qualification and age, average for 2008}

United Kingdom Percentages

In employment,

Not in employment

education or training

education or training

(NEET)

Total

16-17

Degree or equivalent

Higher education below degree level

GCE A Level or equiv

GCSE grades A-C or equiv

Other qualifications

No qualification

Total

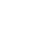

18-24

Degree or equivalent

Higher education below degree level

GCE A Level or equiv

GCSE grades A-C or equiv

Other qualifications

No qualification

Total

\begin{tabular}{rrr}
$*$ & $*$ & $*$ \\
$*$ & $*$ & $*$ \\
12 & 2 & 11 \\
58 & 44 & 57 \\
7 & 20 & 7 \\
23 & 33 & 24 \\
100 & 100 & 100 \\
\hline
\end{tabular}

16-24

Degree or equivalent

Higher educ

GCE A Level or equiv

GCSE grades A-C or equiv

Other qualifications

No qualification

Total

\begin{tabular}{rrr}
13 & 8 & 13 \\
5 & 2 & 4 \\
44 & 15 & 39 \\
24 & 31 & 25 \\
9 & 19 & 11 \\
5 & 26 & 8 \\
100 & 100 & 100 \\
\hline
\end{tabular}

Note:

* Sample too small to provide an estimate.

Table 7

\section{Economic activity status of young people who are NEET, by age and sex, average for 2008}

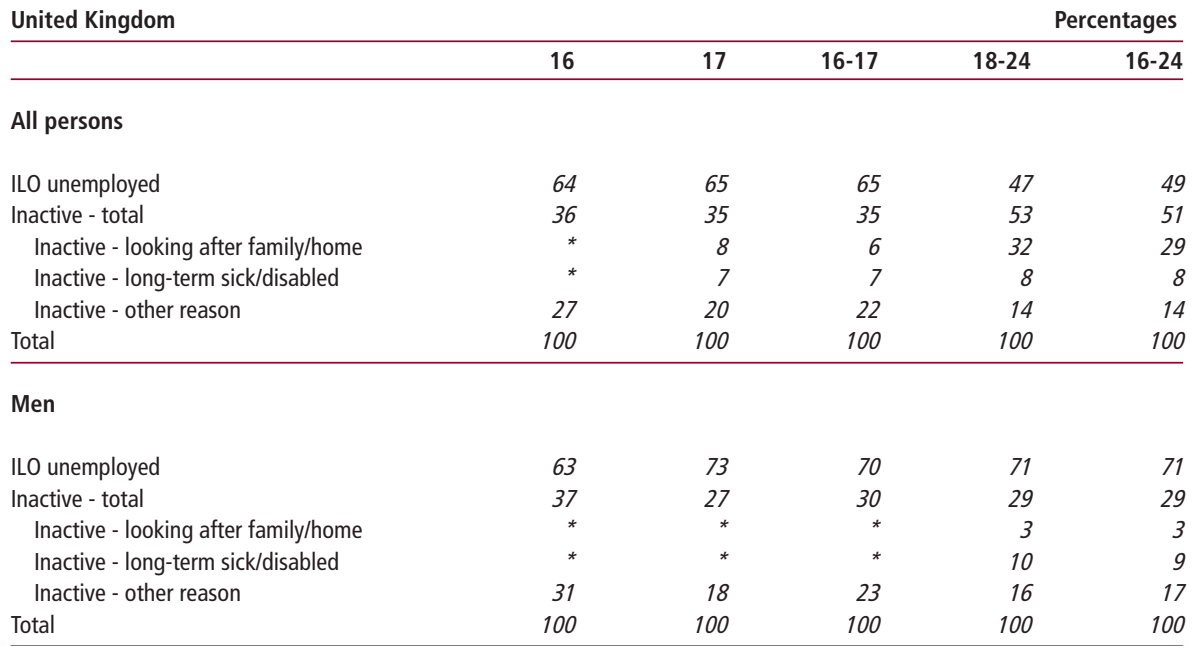

\section{Women}

\section{ILO unemployed \\ Inactive - total \\ Inactive - looking after family/home \\ Inactive - long-term sick/disabled \\ Inactive - other reason}

Total

Note:

* Sample too small to provide an estimate. highest proportions of NEETs were found in Scotland with 10 per cent of this age group being NEET, compared with only 3 per cent in Northern Ireland. There is much less variation in the 18-24 age group with the highest proportion being in the West Midlands at 18 per cent, and the lowest in the South West at 12 per cent.

The section on education and skills of young people earlier in this article indicated that qualifications are key both to the attractiveness of young people to employers and their future prospects in terms of skills and earnings. A key factor in whether or not a young person becomes NEET appears to be linked to the level of qualifications obtained. In 2008, a third of young people aged 16, 17 who were NEET had no qualifications, and a quarter of those aged 18-24 (Table 6). This compares with 23 per cent of non-NEET young people aged 16 , 17 and only 5 per cent of those aged 18-24. These figures are calculated using actual age and therefore the non-NEET group will include many 16 year olds who still in school and have not yet taken GCSEs or other qualifications. If the academic age is used, the proportion of non-NEETs aged 16 and 17 with no qualifications falls to 7 per cent as all of this age group will have completed their GCSE's. This actually increases the difference between the NEET and non-NEET group with no qualifications as 28 per cent of the NEET group of the same age have no qualifications.

Table 7 shows the reasons, in terms of economic activity status, why these young people are NEET. Interestingly, around two thirds of 16 and 17 year old NEETs are unemployed compared to under a half of those in the 18-24 age group. The split between unemployment and inactivity is particularly stark by gender for those young people aged 18-24: 71 per cent of young men of this age were unemployed compared with only 29 per cent of young women of the same age. This is due to the fact that a much larger proportion of young women are NEET as a result of being inactive because they're looking after the family or home: in 2008, 72 per cent of inactive young women aged 16-24 who were NEET gave their reason for inactivity as looking after the family or home. For inactive young men of the same age who were NEET, 32 per cent gave their reason for inactivity as being long term sick or disabled and 57 per cent gave their reason as 'other'.

In order to make some assessment of the propensity of people in the inactive group to work in the future, a new question was added to the LFS in 2005 which 
asked whether the respondent whether they think they will work in the future and when this might be (Kent 2007). It is worth noting that only those who gave the answer 'definitely will work in the future' or 'probably will work in the future' were asked the follow-up question about when this might be. Analysis of the responses to these questions in 2008 show that the difference between the likelihood of young people aged 16 and 17 who are NEET and non-NEET saying they will definitely find a job in the next year is quite striking (Table 8). Among those aged 16-24 who were not NEET, 94 per cent said that they would definitely work in the future. This proportion drops to 65 per cent for those who are NEET. In the 18-24 age group, the difference is even more striking as 93 per cent of those in education or training said they would definitely work in the future compared with only 64 per cent of those young people who were NEET. In terms of when young people thought they would enter or return to employment, 17 per cent of 16-24 year olds in education or training thought this would be in over five years time, presumably as a result of the time taken to complete their studies. What is interesting to note is that 28 per cent of 16 24 year olds who were NEET thought that they would enter or return to employment in over a year's time.

Research carried out by the Department for Education and Skills (DfES) in 2005 found that those who were NEET at 16 years tended to have lower socio-economic status, parents with low or no qualifications, and also tended to have had difficult experiences during Year 11, such as truancy and exclusion. The research also found that parents seemed to play an extremely important role in determining whether young people become NEET. Young people whose parents were involved in their decisions about what to do after Year 11 and had positive attitudes about the value of education were less likely to be NEET. In terms of the ability to move out of the NEET group, the research found that almost half of all those people who were NEET at age 16 were also NEET at 17 , and over a third of those in this group at age 17 were still NEET age 18. In terms of inflows, the highest risk of entering the NEET group was among those who had been in work previously with no training. It was lowest among those who had been in education the previous year.

\section{Family and household circumstances of young people}

Using the APS it is possible to look at the family and household circumstances of young people by whether they are in employment, education or training in 2007. The majority ( 72 per cent) of all young people aged 16 and 17 were living with two parents and just over a quarter were living with one parent (Table 9). The pattern for young people aged 18-24 reflects the transition from living at home to living either with a partner or with other people, excluding partners or parents. In 2007, 18 per cent of young people of this age were living as part of a couple and 17 per cent were living with others.

The table also shows a breakdown by whether or not the young person was NEET. The differences in family and household circumstance between the two groups, NEET or non NEET are fairly stark. In the 16, 17 age group, the difference is largely explained by a much higher proportion of the NEET group living with

Table 8

Economically inactive young people by education status by whether and when they think they will work in the future, average for 2008

United Kingdom

Percentages, rounded to zero decimal places

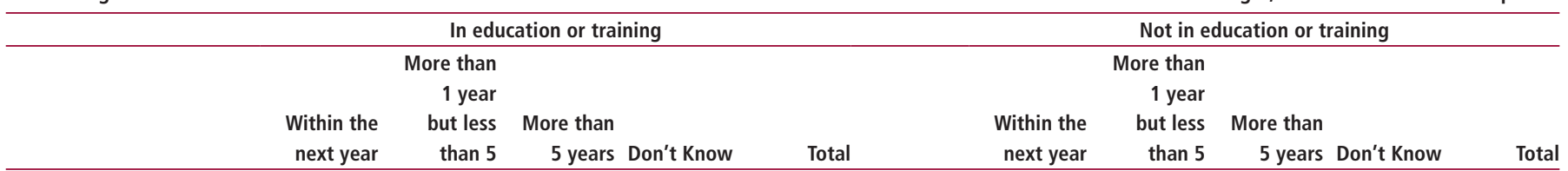

$16-17$

\begin{tabular}{|c|c|c|c|c|c|c|c|c|c|c|}
\hline Definitely will work in future & 21 & 52 & 17 & 6 & 95 & 44 & 21 & * & * & 72 \\
\hline Probably will work in future & 1 & 2 & 0 & 1 & 3 & 6 & 5 & * & * & 16 \\
\hline Probably wont work in future & $n / a$ & $n / a$ & $n / a$ & $n / a$ & 0 & $n / a$ & $n / a$ & $n / a$ & $n / a$ & * \\
\hline Definitely wont work in future & $n / a$ & $n / a$ & $n / a$ & $n / a$ & 1 & $n / a$ & $n / a$ & $n / a$ & $n / a$ & * \\
\hline Don't Know / Can't say & $n / a$ & $n / a$ & $n / a$ & $n / a$ & 1 & $n / a$ & $n / a$ & $n / a$ & $n / a$ & 7 \\
\hline Total & 21 & 54 & 17 & 7 & 100 & 51 & 26 & * & 9 & 100 \\
\hline
\end{tabular}

\section{8-24}

\begin{tabular}{|c|c|c|c|c|c|c|c|c|c|c|}
\hline Definitely will work in future & 28 & 57 & 5 & 4 & 93 & 27 & 28 & 5 & 5 & 64 \\
\hline Probably will work in future & 1 & 3 & 0 & 0 & 5 & 2 & 11 & 4 & 3 & 20 \\
\hline Probably wont work in future & $n / a$ & $n / a$ & $n / a$ & $n / a$ & 1 & $n / a$ & $n / a$ & $n / a$ & $n / a$ & 3 \\
\hline Definitely wont work in future & $n / a$ & $n / a$ & $n / a$ & $n / a$ & 1 & $n / a$ & $n / a$ & $n / a$ & $n / a$ & 5 \\
\hline Don't Know / Can't say & $n / a$ & $n / a$ & $n / a$ & $n / a$ & 1 & $n / a$ & $n / a$ & $n / a$ & $n / a$ & 9 \\
\hline Total & 29 & 60 & 5 & 4 & 100 & 29 & 39 & 8 & 8 & 100 \\
\hline
\end{tabular}

$16-24$

Definitely will work in future Probably will work in future Probably wont work in future Definitely wont work in future Don't Know / Can't say Total

Note:

* Sample too small to provide an estimate.

Totals may not equal the sum of components due to rounding.

\begin{tabular}{rrrrrrrrrr}
25 & 55 & 10 & 5 & 94 & 28 & 28 & 4 & 5 & 65 \\
1 & 3 & 0 & 0 & 4 & 2 & 10 & 3 & 3 & 19 \\
$n / a$ & $n / a$ & $n / a$ & $n / a$ & 0 & $n / a$ & $n / a$ & $n / a$ & $n / a$ & 3 \\
$n / a$ & $n / a$ & $n / a$ & $n / a$ & 1 & $n / a$ & $n / a$ & $n / a$ & $n / a$ & 4 \\
$n / a$ & $n / a$ & $n / a$ & $n / a$ & 1 & $n / a$ & $n / a$ & $n / a$ & $n / a$ & 9 \\
25 & 57 & 10 & 5 & 100 & 30 & 38 & 8 & 8 & 100 \\
\hline
\end{tabular}

Source: Labour Force Survey 
Table 9

Family and household circumstances of young people by whether they are in employment, education or training, January-December 2007

United Kingdom

Percentages

\begin{tabular}{lrrr}
\hline & $16-17$ & $18-24$ & $16-24$ \\
\hline In employment, education or training & & & \\
& & & \\
& & 4 & 51 \\
Living in a one-person household & 72 & 45 & 16 \\
Living with two parents & 25 & 14 & 3 \\
Living with one parent & 0 & 4 & 10 \\
Part of a couple with dependent children & 0 & 13 & 1 \\
Part of a couple without dependent children & 0 & 2 & 15 \\
Lone parent & 2 & 19 & 100 \\
Living with one or more others (not with a partner or parents) & 100 & 100 & \\
Total & & & 10 \\
\hline
\end{tabular}

Not in employment, education or training (NEET)

Living in a one-person household

Living with two parents

Living with one parent

Part of a couple with dependent children

Part of a couple without dependent children

Lone parent

Living with one or more others (not with a partner or parents)

Total

\begin{tabular}{rrr}
1 & 6 & 5 \\
47 & 28 & 31 \\
41 & 17 & 20 \\
2 & 19 & 16 \\
2 & 7 & 6 \\
5 & 16 & 14 \\
3 & 8 & 8 \\
100 & 100 & 100 \\
\hline
\end{tabular}

Total

Living in a one-person household

Living with two parents

Living with one parent

Part of a couple with dependent children

Part of a couple without dependent children

Lone parent

Living with one or more others (not with a partner or parents)

Total

$\begin{array}{rrr}0 & 4 & 3 \\ 70 & 43 & 49 \\ 26 & 14 & 17 \\ 0 & 6 & 5 \\ 0 & 12 & 9 \\ 1 & 4 & 3 \\ 2 & 17 & 14 \\ 100 & 100 & 100\end{array}$

Note:

Source: APS household dataset

0 cells indicate percentage is less than 1 .

Table 10

Young people by whether they are in employment, education or training by the combined economic status of the household in which they live, January-December 2007

United Kingdom

Percentages

$\begin{array}{lllll}16 & 17 & 16-17 & 18-24 & 16-24\end{array}$

In employment, education or training

All adults in the household are working

Household contains both working and non-working adults

None of the adults in the household is working

Total

$\begin{array}{rrrrr}20 & 32 & 25 & 50 & 44 \\ 70 & 60 & 65 & 43 & 48 \\ 10 & 8 & 9 & 7 & 8 \\ 100 & 100 & 100 & 100 & 100\end{array}$

Not in employment, education or training (NEET)

All adults in the household are working

Household contains both working and non-working adults

None of the adults in the household is working

Total

$n / a$

100

\section{$n / a$}

73

27

100

Total

All adults in the household are working

Household contains both working and non-working adults

None of the adults in the household is working

Total

\begin{tabular}{rrrrr}
19 & 29 & 24 & 43 & 39 \\
70 & 61 & 66 & 45 & 50 \\
11 & 10 & 10 & 12 & 12 \\
100 & 100 & 100 & 100 & 100 \\
\hline
\end{tabular}

Source: APS household dataset one parent than in the non-NEET group. In the 18-24 age group, 19 per cent were living as part of a couple with dependent children compared with only 4 per cent of the nonNEET group. This reflects the fact that over half of female NEETs aged 18-24 give their reason for inactivity as looking after family or home.

The APS can also be used to look at the economic status of the adults living in the same household as the young person in 2007. This analysis shows that for the non-NEET group, 8 per cent of young people aged 16-24 are living in a household where no adults are working (Table 10). In comparison, 38 per cent of young people who are NEET are living in a household where no one is working. For the 16, 17 age group, the majority of whom are living with parents, 26 per cent of young people who are NEET are living in a household where no one is working.

\section{Government support}

It is clear that although the proportions of young people who are in the NEET group is relatively small, the concern is that their lack of participation in education or employment at this age is likely to influence their employment prospects in the future. There are a number of policy initiatives which are specifically aimed at young people and are important to bear in mind when looking at labour market experiences of this age group.

\section{Extension of the compulsory school age}

The Education and Skills Act 2008 places a new requirement on all young people in England to participate in education or training until their 18th birthday. This does not necessarily mean staying in school as young people will be able to choose how they participate, which could be in: full time education; work based learning; or parttime training if they are employed, selfemployed or volunteering for more than 20 hours a week.

The age at which young people are required to stay in school will be extended from 16 to 17 from 2013, and 18 from 2015. Current year 7 pupils are the first year where this new legislation will apply.

\section{Connexions Service}

A White Paper 'Learning to Succeed' was published by the government in 2001 . This aimed to set out a single coherent strategy aimed at all young people, called Connexions. This provides a range of guidance and support for 13 to 19 year 
olds in England (and 20-24 year olds with learning difficulties and disabilities). A range of existing public, private, voluntary and community sector organisations have come together to form Connexions Partnerships which develop and coordinate the delivery of support services for young people.

One of the main aims of the Connexions service is to provide financial support for young people who may otherwise be unable to remain in post-16 full time education. Education Maintenance Allowance (EMA) is means tested and available to 16 to 19 year olds. This scheme was initially introduced into 15 pilot areas in 1999 and there is now national coverage in the UK. In an evaluation of the EMA scheme in the pilot stage before full roll-out to the UK, researchers found that financial reasons were a major factor in the decisions of young people in the NEET group who were eligible for EMA, not to continue in post-compulsory education. Other reasons included poor exam results, a dislike of their previous school and difficulties in accessing courses or suitable institutions. The report concludes that the financial incentives offered by EMA may need to be supplemented by other policy responses in order to provide the right support for these groups of young people to carry on in education beyond the age of 16 .

\section{Conclusions}

There appear to be a number of factors affecting the experiences for young people in the labour market today. These include industrial change and the shift from manufacturing industries to the service industries. This has led to a related decline in demand for lower skilled labour. Participation in post-compulsory education has also increased over the last two decades and there is evidence to suggest that young people in education are increasingly being employed. What is of more concern is the fact that youth unemployment still remains higher than for other age groups and the proportion of young people who are not in employment or education (NEET) has not declined.

The analyses in this article highlight the importance of distinguishing between young people who are in education and those who are not. The characteristics of these two groups are distinct as education beyond the age of 16 becomes the norm. Further research is needed to investigate the link between labour market experiences at this age and future labour market prospects and to look particularly at some of the more dynamic elements of the youth labour market, such as using longitudinal information to look at the future labour market experiences of young people who are NEET at some stage.

\section{CONTACT}

凶 elmr@ons.gsi.gov.uk

\section{REFERENCES}

Department for Education and Skills (2005), Young people not in education, employment or training: evidence from the education maintenance allowance pilots database, Research Brief RB628, March (www.dfes.gov.uk/research/)
Department for Education and Employment, Education Maintenance Allowance: The First Year, a quantitative evaluation, Research Report RR257.

Kent K, (2007) New LFS questions on economic inactivity, Economic and Labour Market Review 2007, vol 1, no.12, pp.30-36.

Hicks S, Conn S and Johnson J (2009)

Characteristics of those paid below the National Minimum Wage using the Labour Force Survey, Economic and Labour Market Review 2009, vol 3, no.1, pp.67-73.

Beale I, Bloss C and Thomas A (2008), Longer term impact of the New Deal for Young

People, DWP Working paper 23

Felstead A, H Krahn and D Ashton (1999), Young and old at risk: comparative trends in 'non-standard' patterns of employment in Canada and the United Kingdom. International Journal of Management, 20, pp277-96

Hasluck C (1987) Urban unemployment : local labour markets and employment initiatives, Longman.

Hasluck C (1998), Employers, young people and the unemployed: a review of research. Institute for Employment Research, University of Warwick, Coventry

Maguire S (1993), 'Training for a living: The 1990s Youth Labour Market', Sociology Review, September 2-6. 